Editorial

\title{
Preparedness for Ebola: Can it transform our current public health system?
}

\author{
Mamunur Rahman Malik ${ }^{7}$ and Jaouad Mahjour ${ }^{2}$
}

The devastating Ebola outbreak that raged in west Africa most of 2014 and 2015 has finally come to an end. The epidemic reached unprecedented levels with far reaching implications for global health security. The epidemic, which started in December 2013, killed more than 11000 people and infected at least 28600 (1), more than the total deaths and cases combined reported in the entire history of the disease (2). In addition, it resulted in an unquantified increase in indirect mortality as well as severe societal consequences (3).

On 29 March 2016, on the recommendation of Emergency Committee on Ebola, Dr Margaret Chan, DirectorGeneral of WHO, announced that the Ebola outbreak was no longer a Public Health Emergency of International Concern, while nonetheless stressing the need to maintain a high level of vigilance and response capacity.

It is now the moment to reflect on what lessons have been learnt from the Ebola experience in dealing with epidemic threats in our Region.

The outbreak re-emphasized the importance of reducing the vulnerabilities of societies to infectious disease threats that cross national borders (4). A key lesson, perhaps, was that a weak link in disease detection and control anywhere can be a vulnerability everywhere (5). The other broader lesson that the Ebola epidemic has taught us is that recommended public health capacities, as required under the International Health Regulations (IHR) (2005) but which are widely ignored, are critical to bringing health emergencies under control (6).

The Eastern Mediterranean Region of WHO has remained free of Ebola Virus Disease (EVD) ever since the virus was discovered in 1976. There are no enzootic foci of the virus in the Region. However, population movement through international travel was a major risk of importation of the virus to our Region, particularly since the virus spread beyond Africa for the first time through this mode (2). In view of the threat of importation of EVD, the Regional Committee for the Eastern Mediterranean urged Member States to undertake a comprehensive assessment of their public health capacity to deal with a potential importation. At the request of Member States (7), the Regional Office conducted a rapid assessment of preparedness and readiness measures for preventing, detecting and responding to Ebola in 20 of the 22 countries in the Region at the end of 2014. The assessment was conducted in six core capacities of public health systems needed by all countries to detect, respond and rapidly contain an outbreak of EVD - leadership and coordination, public health measures at points of entry, surveillance and contact tracing, laboratory diagnosis, and risk communication.

The findings showed that in almost every country in the Region, the public health systems were inadequate to respond effectively to a severe, sustained and wide-spreading health threat like EVD. In view of the fragility of the health systems, a 90-day plan of action was therefore drawn up and implemented between March and May 2015 to support the vulnerable countries in stepping up their preparedness and operational response for EVD.

Now that the threat of EVD is over and other competing priorities divert political attention, the momentum generated by the 90 -day action plan to address systemic weaknesses in health systems for outbreak prevention, detection and response needs to be maintained. This requires strong political determination to transform the national public health systems of the countries and ensure their resilience. It is clear that many of these weaknesses correspond to the IHR (2005) core capacities that every country is required to have to prevent detect and respond to epidemic threat. We should therefore use the EVD assessment findings to develop time-bound medium- and long-term strategic plans to close the gaps with appropriate monitoring mechanisms in order to measure progress in the required capacity building.

As the Ebola epidemic fades from our memories, we risk missing a window of opportunity if we do not move with a sense of urgency now. Just as the Ebola outbreak was being brought under control, another global health emergency arose and is ongoing - Zika virus infection. While Ebola did not strike the Region and Zika virus infection has yet to hit, the threats are very real. The continuing transmission of Middle East respiratory syndrome coronavirus (MERS-CoV) in our Region and the surge of pandemic potential 
highly pathogenic avian influenza virus infection in Egypt remain grave global concerns.

Establishing or reinforcing a system that is much more prepared than before to detect, monitor and rapidly respond to acute health threats is a moral imperative for every nation. This can best be achieved by investing in an equitable and accessible public health system that is grounded in primary health care principles; this will not only provide security against an epidemic threat, it will also help people meet their every-day health needs (8).
Although the reputation of $\mathrm{WHO}$ has suffered as a result of its initial response to the Ebola outbreak (9), there is no other single organization than WHO with the technical knowledge, information and skills necessary to operationally respond to outbreaks when national capacities are overwhelmed, even when these escalate to humanitarian emergencies (10). WHO has learned and is learning from the Ebola crisis and is working to enhance its capability to lead international efforts to strengthen and monitor the most vulnerable countries' capacity for preparedness, readiness, response and recovery to acute public health threats. Countries need to do the same and take action to ensure their public health capacities meet those required under the IHR (2005).

In today's world, the infectious diseases threats will emerge and spread faster than before without respect for political or geographic boundaries. Any inaction either from the countries or from WHO and other international health partners will only compromise our global health security.

\section{References}

1. World Health Organization. Situation Report of Ebola - 16 March 2016. (http://apps.who.int/ebola/current-situation/ ebola-situation-report-16-march-2016, accessed 23 March 2016).

2. Frieden TR, Damon I, Bell BP, Kenyon T, Nichol S. New challenges, new global response and responsibility. $\mathrm{N}$ Engl J Med. 2014 Sep 25;371(13):1177-80. PMID: 25140858.

3. Checchi F, Waldman RJ, Roberts LF, Ager A, Asgary R, Benner MT, et al. World Health Organization and emergency health: if not now, when? BMJ. 201601 28;352:i469. PMID:26821569

4. Heymann DL, Chen L, Takemi K, Fidler DP, Tappero JW, Thomas MJ, et al. Global health security: the wider lessons from the west African Ebola virus disease epidemic. Lancet. 2015 May 9;385(9980):1884-901. PMID:25987157

5. Frieden TR. SHATTUCK LECTURE: The Future of Public Health. N Engl J Med. 2015 Oct 29;373(18):1748-54. PMID:26510022

6. Gostin LO, Friedman EA. A retrospective and prospective analysis of the west African Ebola virus disease epidemic: robust national health systems at the foundation and an empowered WHO at the apex. Lancet. 2015 May 9;385(9980):1902-9. PMID:25987158
7. WHO Regional Committee for Eastern Mediterranean resolution EM RC61/R.2. Global health security-challenges and opportunities with special emphasis on the International Health Regulations. Cairo: WHO Regional Office for Eastern Mediterranean; 2014 (http://applications.emro.who.int/docs/ RC61_Resolutions_2014_R2_15554_EN.pdf?ua=1, accessed 23 March 2016).

8. Kieny MP, Dovlo D. Beyond Ebola: a new agenda for resilient health systems. Lancet. 2015 Jan 10;385(9963):91-2. PMID:25706456

9. Moon S, Sridhar D, Pate MA, Jha AK, Clinton C, Delaunay S, et al. Will Ebola change the game? Ten essential reforms before the next pandemic. The report of the Harvard-LSHTM Independent Panel on the Global Response to Ebola. Lancet. 2015 Nov 28;386(10009):2204-21. PMID:26615326

10. Kamradt-Scott A, Harman S, Nunes J, Roemer-Mahler A, Wenham C. WHO must remain a strong global health leader post Ebola. Lancet. 2015 Jan 10;385(9963):111. PMID:25706459 